Civil Engineering

Volume 170 Issue CE3

Electrokinetic geosynthetics: from research to hype to practice

Jones, Lamont-Black, Huntley, Alder and Glendinning

ice | proceedings
Proceedings of the Institution of Civil Engineers Civil Engineering 170 August 2017 Issue CE3 Pages 127-134 http://dx.doi.org/10.1680/jcien.16.00039 Paper 1600039

Received 04/10/2016

Published online 05/04/2017

Keywords: geotextiles, membranes \& geogrids/slopes

stabilisation/waste management \& disposal

ICE Publishing: All rights reserved

\title{
Electrokinetic geosynthetics: from research to hype to practice
}

Colin Jones BSC, MSc, PhD, CEng, FICE

Emeritus Professor, Newcastle University, Newcastle upon Tyne, UK

John Lamont-Black BSc, PhD

Chief Executive, Electrokinetic Limited, Newcastle upon Tyne, UK

David Huntley BA, FACMA

Director, Electrokinetic Limited, Newcastle upon Tyne, UK
David Alder MEng

Technical Engineer, Electrokinetic Limited, Newcastle upon Tyne, UK

Stephanie Glendinning BSC, PhD, FICE

Professor of Civil Engineering, Newcastle University, Newcastle upon Tyne, UK

Electrokinetic geosynthetics enable civil engineers to put electrical energy into the ground to stiffen it and control groundwater flows. This paper summarises the evolution of the technology over the past 25 years, from research by way of hype and into practice. It was conceived in 1993 at Newcastle University in the UK, combining established knowledge of geotextiles with historical studies of electrokinetics. A series of UK government-funded research programmes helped to generate global interest in its possible applications, leading to a technology spin-off company being incorporated in $\mathbf{2 0 0 1}$ to attract private venture capital investment and further development funding. This eventually narrowed down the practical applications to slope stabilisation and dewatering, which now form the company's main revenue streams.

\section{Introduction}

Geosynthetics are widely used in the civil engineering, waste, water and mining industries. They normally play a passive or reactive role. For example, geosynthetic reinforcement provides tensile resistance but only after an initial strain has occurred, while a geosynthetic filter or drain provides a passage for water but only after water flows towards it.

In 1994 it was postulated that an entirely new spectrum of applications for geosynthetics was possible if they could provide an active role - initiating biological, chemical or physical change to the matrix in which they were installed as well as providing the established functions (EPSRC, 1994).

It was suggested that geosynthetic inclusions in soil could be transformed into having an active role by making the material electrically conductive. Filtration, drainage, containment and reinforcement functions could be enhanced by electrokinetic techniques that stiffened the soil, improved the soil-reinforcement bond and enabled rapid transport of water and chemicals within fine-grained low-permeability materials. Increasing soil strength is a function of electrokinetic drainage and ion migration. Electrokinetically enhanced water flow through normally impermeable materials also permits the introduction of conditioning fluids.

The concept of electrokinetic geosynthetic materials, developed at Newcastle University in the UK, was first introduced at the Third International Geosynthetics Symposium in Japan in 1996 (Jones et al., 1997). Development of electrokinetic geosynthetic technology from research to practice was made possible by three Engineering and Physical Sciences Research Council (EPSRC) grants and a Technology Strategy Board Award (Innovate UK), supported by funding from industry in the UK, Germany, Japan, South Africa and Sweden.

This paper introduces the concept of electrokinetic geosynthetics and describes, briefly, the fundamental research studies and findings used to establish the controlling criteria of the technology. Following the research phase, development of the technology for practical application was undertaken by the creation of a university spin-out company working with interested parties from industry.
The application of the technology to the stabilisation of failed and failing slopes, consolidation of weak subsoils, dewatering of difficult materials and the treatment and reduction of waste is now established practice, which has been shown to provide both economic and environmental benefits. Other application areas are in development.

\section{Concept development}

The concept of electrokinetic geosynthetics was initially developed with EPSRC funding from 1994-1997 (EPSRC, 1994). The main technical components, which form the base of electrokinetic geosynthetic technology, are shown in Tables 1 and 2 .

Table 1 shows that electrokinetics and geosynthetics have 14 separate functions between them. By combining these functions, a range of electrokinetic geosynthetic materials can be produced, each with unique properties. These may be selected and controlled according to the materials and settings in which they are to be used, the physical and chemical design, electrical control and operation, and management of boundary conditions. Table 2 shows the key electrokinetic parameters, their effects and practical functions that can be exploited by electrokinetic geosynthetics.

Table 1. Functions used in practical applications of electrokinetic geosynthetics

\begin{tabular}{|l|l|}
\hline Electrokinetic function & Geosynthetic function \\
\hline Electro-osmosis & Drainage \\
\hline Electrophoresis & Reinforcement \\
\hline Ion migration & Filtration \\
\hline Electrolysis of water & Separation \\
\hline Heating & Containment \\
\hline Oxidation reactions & Membrane action \\
\hline Reducing reactions & Sorption \\
\hline
\end{tabular}


Table 2. Key parameters, their effects and practical implications of the main electrokinetic functions of electrokinetic geosynthetic materials

\begin{tabular}{|c|c|c|c|}
\hline Electrokinetic component & Parameter & Effect & Practical implication \\
\hline \multirow[t]{2}{*}{ Electro-osmosis } & Water flow rate, $Q=\left(k_{\mathrm{e}} \mathrm{V}\right) /(L A)$ & Drainage and water content & $\begin{array}{l}\text { Produces water movement in fine- } \\
\text { grained materials }\end{array}$ \\
\hline & Pore water pressure, $u=\left(k_{\mathrm{e}} / k_{\mathrm{h}}\right)(V / L)$ & Consolidation or decompaction & $\begin{array}{l}\text { Produces consolidation in compressible } \\
\text { materials }\end{array}$ \\
\hline \multirow[t]{2}{*}{ Electrolysis } & $\mathrm{pH}(\Delta \mathrm{pH}=f(/ / A))$ & Acid/alkali changes & Permits control of $\mathrm{pH}$ \\
\hline & {$\left[\mathrm{O}_{2}\right],\left[\mathrm{H}_{2}\right]\left(\Delta\left[\mathrm{O}_{2}\right],\left[\mathrm{H}_{2}\right]=f(/ / A)\right)$} & Oxygenation (redox potential) & $\begin{array}{l}\text { Promotes root/growth and soil } \\
\text { microbial activity }\end{array}$ \\
\hline Electrokinetic hardening & $f \mathrm{pH}$. CEC. electrode composition & Stiffening of soil and waste & Slope and tailings stabilisation \\
\hline Joule heating & $f=R R$ and conductivity of material & Heat generation & $\begin{array}{l}\text { Increases chemical activity and } \\
\text { microbial activity }\end{array}$ \\
\hline
\end{tabular}

The initial research confirmed that electrokinetic geosynthetics were viable and led to the first patent for the structure of an electrokinetic geosynthetic material being granted (Eng and Jones, 1998). It was found that electrokinetic geosynthetics can take the form of a single material which is electrically conductive, or a composite material, in which at least one element is electrically conductive. They can be of the same basic form as present-day filter, drainage, separator and reinforcement materials, but offer sufficient electrical conduction to allow the application of electrokinetic techniques.

A series of laboratory studies was undertaken to evaluate the use of conductive geotextiles as electrodes in electro-osmotic consolidation and reinforced soil. The types of geosynthetics used included conductive needle-punched geotextiles, carbon-fibre material and modified-polyester reinforcing tape. The latter was made electrically conductive by the addition of conductive stringers aligned parallel to the polyester reinforcing elements.

In reinforced-soil tests, an electrokinetic geosynthetic reinforcing element was used as an anode with the cathode formed from a needle-punched electrokinetic geosynthetic. The results of pull-out tests showed an increase in reinforcement bond of $211 \%$ and increases in undrained soil shear strength of $123 \%$ compared to the values obtained when the geosynthetic inclusions were not electrically conductive.

In consolidation trials of fine-grained soils, the electrokinetic geosynthetic electrodes were found to function as well as copper electrodes but with better durability in both normal and reverse polarity configurations (Hamir et al., 2001; Jones, 2000; Jones et al., 1997, 2002). Nettleton continued the work presented by Jones et al. (1997). He suggested that an electrode similar in form to a band drain would be the most suitable configuration to fulfil the electrode requirements associated with consolidation, bioremediation of contaminated ground and moisture control in embankments (Nettleton et al., 1998).

The first practical electrokinetic geosynthetic for use in fullscale structures was produced by Netlon Limited in 1998 (Netlon Ltd, 1998). This material was used in all the initial field trials undertaken to demonstrate the applicability of the electrokinetic geosynthetics concept. It is still used as electrokinetic geosynthetic electrodes in laboratory-based research studies in a number of countries but has been superseded by more durable materials for practical use.

\section{UK government-funded studies}

A second EPSRC award was granted in 1997 to study the use and application of electrokinetic geosynthetics in the construction industry (EPSRC, 1997). The objectives of the research were to undertake field trials covering electro-osmotic consolidation, the strengthening of cohesive soil, volumetric control of clay embankments and to identify design methodologies. The research was undertaken with industrial collaborators from UK, Germany, Japan and Sweden.

The study identified acceptability criteria for the assessment of the suitability of a soil for treatment by electrokinetics based upon standard soil-mechanics laboratory tests enhanced by electro-osmosis (Table 3). Characterisation of the effectiveness of dissimilar electrode installation arrays was also developed based on finite-difference and resistance-path techniques.

Table 3. Utility of soil tests for assessing acceptability for electrokinetic treatment

\begin{tabular}{|c|c|c|}
\hline Test & Usefulness $^{\mathrm{a}}$ & Acceptability range \\
\hline Atterberg limits & $\checkmark \checkmark \checkmark$ & 5-30\% P.I. \\
\hline Water content & $\checkmark \checkmark \checkmark$ & $0 \cdot 6-1 \cdot 0$ L.I. \\
\hline $\begin{array}{l}\text { Particle size distribution - } \\
\text { sieve and sedimentation }\end{array}$ & $\checkmark \checkmark$ & Within clay silt range \\
\hline Particle density & $\checkmark \checkmark \checkmark$ & Not applicable \\
\hline Organic content & $\checkmark \checkmark \checkmark$ & Up to organic \\
\hline $\begin{array}{l}\text { One-dimensional } \\
\text { consolidation parameters }\end{array}$ & $\checkmark \checkmark \checkmark$ & $m_{\mathrm{v}}=0.3-1.5 \mathrm{MN} / \mathrm{m}^{2}$ \\
\hline Disk electrode & $\checkmark \checkmark$ & $0.05-0.005 \mathrm{~S} / \mathrm{m}$ \\
\hline Hydraulic permeability & $\checkmark \checkmark$ & $<10^{-8} \mathrm{~m} / \mathrm{s}$ \\
\hline Undrained shear strength & $\checkmark \checkmark \checkmark \checkmark$ & $<55 \mathrm{kPa}$ \\
\hline Drained shear strength & $\checkmark \checkmark \checkmark \checkmark$ & $\phi^{\prime}<30$ \\
\hline Electro-osmosis cell & & Comparison with control \\
\hline Electrokinetic shear box & & Comparison with control \\
\hline \multicolumn{3}{|c|}{ a $\checkmark \checkmark \checkmark \checkmark=$ excellent, $\checkmark \checkmark \checkmark=$ good, $\checkmark \checkmark=$ useful } \\
\hline
\end{tabular}


A field study of electro-osmotic consolidation of a soft soil was undertaken at Newburn in Newcastle, UK (Pugh et al., 2000). From the trial, a method for predicting the quantity of consolidation that can be achieved using electrokinetic geosynthetic technology was developed. The method is based upon a linearly equivalent surcharge varying from $0 \mathrm{kPa}$ at the cathode to a maximum of $100 \mathrm{kPa}$ at the anode. The method was confirmed by laboratory testing on horizontal electrodes located in a block of London Clay together with the back-analysis of published case studies.

The study also included the first ever field application of electroosmosis to cohesive reinforced soil (Glendinning et al., 2005a; Jones and Pugh, 2001). The trial was unique in that a vertical $5 \mathrm{~m}$ reinforced soil wall was constructed using liquid fill (Figure 1). The fill was strengthened between lifts $300 \mathrm{~mm}$ high by electro-osmosis provided by the top two layers of reinforcement at each lift acting as electrodes. The lower electrode acted as an anode and the upper as a cathode; hence drainage was upwards towards the surface of the fill.

Once strengthening of the lift had been achieved, the lower electrode (anode) was deactivated and assumed a reinforcement role, while the upper electrode (cathode) was changed to an anode ready for the next lift by reversing the polarity. A design methodology for electrokinetic reinforced cohesive soil was then developed based upon long- and short-term design and electro-osmotic criteria. The typical cost was shown to be approximately $£ 300$ per square metre, indicating it could be achieved economically.

The third element of the 1997 research funding related to controlling volume change in susceptible soils. It was established that the negative pore-water pressure generated by electro-osmosis results in over-consolidation of the soil, such that subsequent wetting and drying cycles result in reduced swelling and shrinkage. The electrokinetic process also causes electrochemical cementing, making soils less prone to volume change.

A third EPSRC research award in 2005 was aimed at studying the ability of electrokinetic geosynthetic drains to remove liquids from wastes for waste minimisation and resource recovery (EPSRC, 2005). The research demonstrated that electrokinetic geosynthetic technology could be used to revolutionise how wastes, sewage and slurries are disposed of. By removing water, the dry solids content is increased together with a significant reduction in volume. In some cases, the increase in dry solids causes the waste to become auto-thermic, thus enabling it to be used as fuel (Glendinning et al., 2006, 2008; Hall et al., 2008).

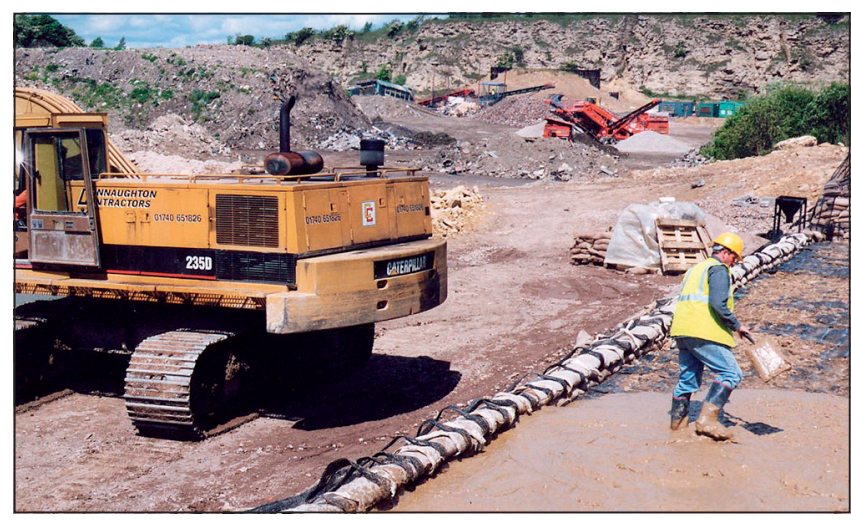

Figure 1. Construction of a $5 \mathrm{~m}$ tall reinforced soil wall using liquid cohesive soil - each $300 \mathrm{~mm}$ lift was consolidated using electro-osmosis (after Jones and Pugh, 2001)

\section{University-funded studies}

In addition to EPSRC-funded research, a number of MSc and $\mathrm{PhD}$ studies into the concept of electrokinetic geosynthetic materials and their uses have been conducted. These include co-operative research and development studies at Birmingham University, University of Western Australia, Wuhan University China, Irstea-Unite HBAN France, Sachsicestextil Forschungs Institute Germany and Witwatersrand University South Africa.

They made notable progress in enhancing the understanding of the concept of electrokinetic geosynthetic technology as well as identifying new application areas (Jones et al., 2008). They included the use of electrokinetic geosynthetics in enhancing sports turf technology, strengthening of soft soils, stabilisation of slopes, treatment of contaminated soils and treatment of sewage sludge (Glendinning et al., 2005b, 2006; Lamont-Black and Jones, 2006; Lamont-Black et al., 2006a).

The electrokinetic treatment of mine tailings demonstrated that dewatering of mine tailings using electrokinetic geosynthetic methods could be economic as well as effective (Fourie and Jones, 2010; Fourie et al., 2002, 2004, 2007; Pavlakis et al., 2001, 2002).

The use of electrokinetic geosynthetic reinforcement to stabilise slopes has also been studied in China together with the consolidation of deep marine deposits to provide building land (Zhuang and Wang, 2005).

Recent studies in France have considered the development of electrokinetic geosynthetic composite materials to dewater tar sands (Bourges-Gastaud et al., 2015).

\section{Practical development}

In 2001 EPSRC declared electrokinetic geosynthetics a 'platform technology' and a year later it was exhibited in the Science Museum, London during the 2002 FIFA World Cup. This comprised a working model of how to create the perfect football pitch, in which electrokinetic geosynthetic materials were used to control drainage as well as provide oxygen and heat to promote root growth and microbial activity (Figure 2) (Lamont-Black and Jones, 2006).

The fundamental research studies demonstrated that electrokinetic geosynthetics represented a new technology that could have a significant effect on industry practice and environmental impact reduction. To realise the potential and commercialise the technology,

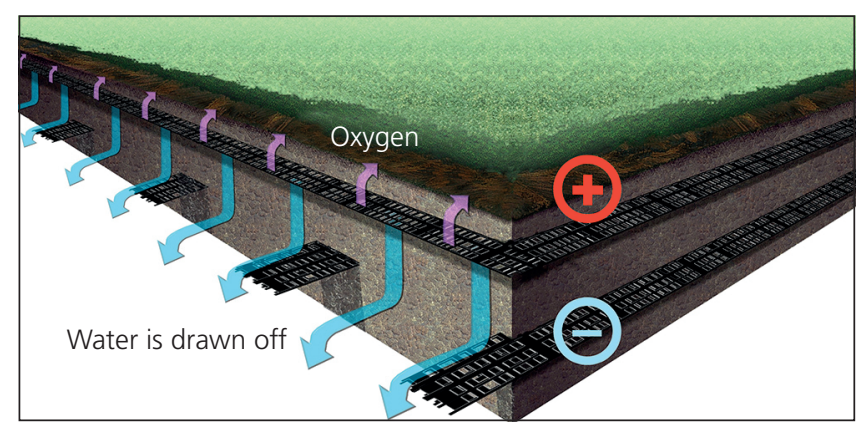

Figure 2. How electrokinetic geosynthetics could be applied to sports turf to control drainage and provide oxygen and heat to promote root growth and microbial activity 
Newcastle University set up a spin-out company - Electrokinetic Limited - funded by private and venture capital.

Transferring laboratory-based research findings to practice requires the acceptance of the technology by the relevant authorities and the development of materials and construction protocols to meet established industry standards. As part of the basic studies into electrokinetic geosynthetics, technology protocols have been developed to determine the electrokinetic properties of soils, tailings and waste sludges.

The electrical conductivity of a fine-grained material can be determined according to BS 1377 (BSI, 1990). The coefficient of electro-osmotic permeability may be determined using a modified permeameter using the Helmholtz-Smoluchowski model of electro-osmotic flow (Smoluchowski, 1914). Electro-osmotic consolidation can be determined in a modified (non-conductive) triaxial cell (Glendinning et al., 2005a).

Assessment of the improvement in soil-reinforcement bond strength during electrokinetic treatment can be determined in the laboratory using an electrokinetic shear box. This is based on a conventional shear box formed from non-conductive materials in which, in addition to the conventional normal load to which the specimen is subjected, a voltage gradient is also applied. The voltage gradient is equivalent to that proposed in the field.

\section{UK government technology programme}

A major boost to commercialising electrokinetic geosynthetics technology was provided by a UK government campaign to support business in taking new ideas and technologies from the laboratory to the market (TSB, 2005). In 2005, the government's Department for Trade and Industry co-funded a $£ 1.5$ million project to apply the electrokinetic geosynthetic concept to strengthening soils and treatment and minimisation of waste slurries, sludge and sewage.

The partners in the project included Electrokinetic Limited, Newcastle University, C A Blackwell, Edmund Nuttall, GKD (Germany), Rio Tinto Mining Company, Severn Trent Water and Yorkshire Water. The project covered four areas of development prefabricated drain material, treatment of waste, consolidation of in situ sludge lagoons and tailings, and conditioning and composting.

The original Netlon electrokinetic geosynthetic material for prefabricated drains was found not to provide long-term (60120 year) durability, so a more robust electrokinetic geosynthetic drain was developed. This conforms to the specifications demanded in permanent works associated with slope stabilisation.
The material is a composite based around a porous polymeric pipe, which includes a geosynthetic filter and a circular braided bi-metallic mesh conductor. The material is also used in situ to consolidate soft soils.

Table 4 shows the potential electrokinetic methods available using different material forms. The electrokinetic belt-press is a continuous method of dewatering materials, electrokinetic prefabricated drains are used in situ and electrokinetic bags and tubes are suitable for batch processes.

The result of using electrokinetic geosynthetics technology in sewage dewatering by Thames Water Company (London) is shown in Figure 3. Similar results were obtained in Germany. The economics and cost savings of using electrokinetic geosynthetic technology to dewater sewage sludge has been identified by Huntley et al. (2006), Lamont-Black et al. (2006b) and McLoughlin (2005). Figure 4(a) shows the nature of material that can be treated and Figure 4(b) shows the same material following treatment at $30 \mathrm{~V}$ for a period of $48 \mathrm{~h}$.

The technology programme also demonstrated that electrokinetic geosynthetic materials could provide in situ dewatering of sludge

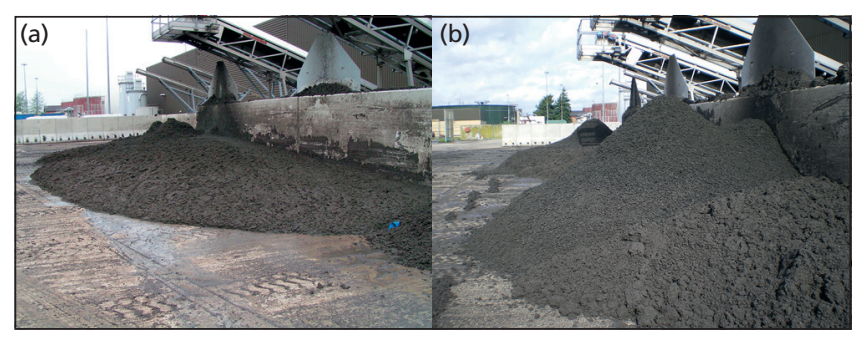

Figure 3. Conventionally dewatered waste (a) and electrokinetically dewatered waste with a $39 \%$ volume reduction (b)

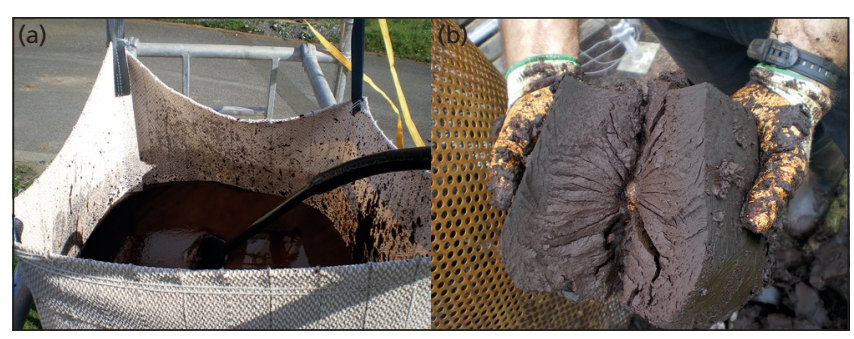

Figure 4. Filling an electrokinetic dewatering bag (a) and solidified material following treatment with $30 \mathrm{~V}$ for $48 \mathrm{~h}$ (b)

Table 4. Electrokinetic geosynthetic treatment of wastes

\begin{tabular}{|c|c|c|c|c|c|}
\hline \multirow[t]{3}{*}{ Materials } & \multirow{3}{*}{$\begin{array}{l}\text { Treatment } \\
\text { method }\end{array}$} & \multicolumn{4}{|c|}{ Supply } \\
\hline & & \multicolumn{2}{|c|}{ Constant } & \multicolumn{2}{|c|}{ Intermittent } \\
\hline & & Large volume & Small volume & Large volume & Small volume \\
\hline \multirow{2}{*}{ Homogeneous } & Existing & $\begin{array}{l}\text { Belt presses, plate } \\
\text { presses and centrifuges }\end{array}$ & Small belt, transport & Temporary lagoon & $\begin{array}{l}\text { Transport, mobile } \\
\text { dewatering }\end{array}$ \\
\hline & $\begin{array}{l}\text { Electrokinetic } \\
\text { geosynthetic }\end{array}$ & Electrokinetic belt presses & Electrokinetic belt & Electrokinetic tubes & Electrokinetic bags \\
\hline \multirow{2}{*}{ Mixed } & Existing & $\begin{array}{l}\text { Screen plus thicken and } \\
\text { dewater }\end{array}$ & $\begin{array}{l}\text { Screen thicken and } \\
\text { transport }\end{array}$ & Temporary lagoon & $\begin{array}{l}\text { Screen thicken and } \\
\text { spread }\end{array}$ \\
\hline & $\begin{array}{l}\text { Electrokinetic } \\
\text { geosynthetic }\end{array}$ & $\begin{array}{l}\text { Screen plus electrokinetic } \\
\text { belt or tube }\end{array}$ & Electrokinetic bags & Electrokinetic tubes & Electrokinetic bags \\
\hline
\end{tabular}


lagoons (Jones et al., 2002, 2011; Walker and Glendinning, 2002). It also involved bench-scale tests followed by a full-scale $50 \mathrm{~m}$ long compost windrow, which showed that electrokinetic geosynthetics can be used to improve the dewatering and aeration of sludgeconditioning operations. Details of the results of full-scale tests of electrokinetic composting have been provided by White et al. (2008).

\section{Product manufacture and standards}

In the development of electrokinetic geosynthetics technology, various material forms have been developed for use in specific applications. Electrokinetic drains and soil nails have been developed to stabilise failed and failing slopes and for in situ consolidation of soils and wastes. Electrokinetic belts have been developed for dewatering sewage and mine tailings in belt filter presses, while electrokinetic dewatering bags have been produced for treating and disposal of small volumes of wastes which are difficult to treat.

Over 40 material suppliers have been associated with the manufacture and installation of electrokinetic geosynthetics, including Afitex (France), Arcitex (Sweden), Belton (USA), Clear Edge (Sweden), GKD (Germany) and Technitex Sachsen (Germany). In the UK, Ashbrook Simon Hartley has developed an electrokinetic belt press machine for dewatering waste and tailings, and self-climbing rigs have been adopted and developed to install electrokinetic geosynthetic electrodes in slopes without the need to remove established trees. In addition, both Highways England and Network Rail have funded the manufacture of direct current voltage rectifiers used during the active treatment phase of slope stabilisation and dewatering of lagoons.
The development of electrokinetic geosynthetics has been recognised by British Standards and the revised BS 8006:1 (BSI, 2010) allows their use in reinforced soil structures. The development of the technology makes it possible to meet a major objective of the revised BS 8006 of enabling the greater use of previously unacceptable waste materials as fill in reinforced soil structures. This has enabled electrokinetic soil nailing to be used in conditions not previously possible, resulting in reductions in the cost of works and carbon dioxide emissions.

The International Geosynthetics Society has also developed graphical symbols and terminology covering electrokinetic geosynthetic applications (IGS, 1996).

\section{Practical applications}

The underpinning research and development stages of electrokinetic geosynthetic technology have identified a range of new applications which cannot be addressed by conventional geosynthetics - see Table 5 .

The benefits and drivers for the use of electrokinetic geosynthetic applications include reduced cost, improved productivity, reduced carbon dioxide emissions, reduced waste, water recovery, suppression of liquefaction in soils and tailings, improved performance and resolved construction problems.

\subsection{Slope stabilisation, UK}

Both Highways England and Network Rail are open to innovation and two critical case histories - one associated with the stabilisation of a railway embankment, the other a highway slope - have illustrated

Table 5. Industries, markets and sectors identified as relevant electrokinetic geosynthetic applications

\begin{tabular}{|c|c|c|c|}
\hline Industry & Market & Market sector & Electrokinetic geosynthetic application \\
\hline \multirow[t]{5}{*}{ Water } & \multirow[t]{3}{*}{ Sewage treatment } & Dewatering machinery & Belt/plate filter press \\
\hline & & Composting & Prefabricated drain \\
\hline & & Dewatering & Dewatering bag \\
\hline & \multirow[t]{2}{*}{ Water treatment } & Dewatering & Belt filter press \\
\hline & & Consolidation & Prefabricated drain \\
\hline Food & Processed food waste & Dewatering & Belt filter press/dewatering bag \\
\hline \multirow[t]{4}{*}{ Mining } & Mineral sands & Dewatering & Belt filter press \\
\hline & Diamond tailings & Dewatering & Belt filter press \\
\hline & Coal and coal waste & Dewatering & Belt filter press \\
\hline & $\begin{array}{l}\text { Tailings lagoon stabilisation and } \\
\text { combating liquefaction }\end{array}$ & Stabilisation & Prefabricated drain/soil nails \\
\hline \multirow{8}{*}{$\begin{array}{l}\text { Civil } \\
\text { engineering }\end{array}$} & Ground engineering & Dewatering & Dewatering bag/belt filter press \\
\hline & \multirow[t]{2}{*}{ Waterways engineering } & Dewatering dredgings & Dewatering bag \\
\hline & & Embankment stabilisation & Prefabricated drain/soil nails \\
\hline & Railway and highway maintenance & Slope and embankment stabilisation & Prefabricated drain/soil nails \\
\hline & General and highway construction & Reinforced soil and ground consolidation & Reinforcement/prefabricated drain \\
\hline & $\begin{array}{l}\text { Brownfield development and land } \\
\text { reclamation }\end{array}$ & $\begin{array}{l}\text { Ground consolidation and waste } \\
\text { solidification }\end{array}$ & Prefabricated drain \\
\hline & $\begin{array}{l}\text { Highway maintenance and dewatering } \\
\text { gulley waste }\end{array}$ & Waste solidification & Dewatering bag \\
\hline & Nuclear waste & Solidification and reduction & Dewatering bag \\
\hline Sport & Turf and pitches & Football and cricket & Prefabricated drain/mat \\
\hline
\end{tabular}


the economic and environmental benefits that electrokinetic geosynthetics can provide. The case histories showed cost savings of $25-30 \%$ and reduction in carbon dioxide emissions of $46 \%$ when compared with conventional construction techniques (Jones et al., 2014). These benefits are close to the targets identified in the UK government's Construction 2025 industrial strategy (BIS, 2013).

Compared with traditional methods, a growing number of case histories show the electrokinetic geosynthetic slope stabilisation technique offers improvement in construction productivity, fewer lorry movements, zero waste removal, minimal material import, reduced noise and vibration, improved air quality, preservation of the seed bank and soil environment, minimal vegetation clearance with almost all trees being retained, no visual impacts, no disruption to passing motorists and less damage to root protection areas.

The construction of slope stabilisation and repair is often intensive, difficult and hazardous and usually involves significant disturbance to the local environment. Electrokinetic geosynthetic slope stabilisation is a multifunctional approach which combines ground improvement, reinforcement and drainage into a single array of multifunctional elements (Figure 6), which act synergistically during construction and in service. In acting this way the combined remediation effect is maximised while the construction intensity and environmental disturbance is minimised.

Electrokinetic geosynthetic slope stabilisation is applicable to ground conditions dominated by, and failure modes controlled by, fine-grained soils, which may include weathered mantles of mud rocks. These include fine-grained peat deposits but exclude fibrous peat. It is inapplicable, however, to mud rocks and failure mechanisms dominated by brittle failure or granular washout. The design principles of electrokinetic geosynthetic slope stabilisation and case histories have been presented by Alder et al. (2015), Jackson et al. (2015), Jones (2011) and Lamont-Black et al. (2007a, 2012, 2016).

\subsection{Dewatering, UK}

The dewatering of medium volumes of miscellaneous wastes and sludges can be achieved rapidly and without the development of major infrastructure using electrokinetic bags. Examples of the types of materials that have been dewatered include dredgings, water clarification slurry, anaerobically digested waste, nuclearcontaminated waste and road gully waste.

Figure 5 shows the dewatering of nuclear-contaminated waste sludge. In this application, the volume of nuclear waste requiring long-term storage was reduced by $90 \%$ (Lamont-Black et al., 2015).

\subsection{Consolidation of hydraulically placed fill, China}

In China, the large-scale application of electro-osmotic consolidation of very soft deposits to permit the construction of light industry and housing is being pursued using electrokinetic vertical drains. Treatment of deep deposits by electrokinetic geosynthetics has been shown to be more economic and effective than vacuum preloading (Zhuang, 2015; Zhuang et al., 2014). Recent developments are applying this technique to consolidation of soft highly saline marine margin soils.

\subsection{Dewatering of mine tailings, South Africa}

Mineral mining has a major environmental impact with regard to the carbon dioxide emissions of the operations, very high demand for water and excessive energy costs associated with the disposal of tailings.
Laboratory trials of the electrokinetic dewatering potential of tailings from Kimberley, Orapa and Premier diamond mines in Botswana and South Africa established that they can be treated using electrokinetic belt press technology (Lamont-Black et al., 2007b). Full-scale trials at Kimberley have demonstrated that major savings can be obtained with regard to energy costs associated with disposal, reduction in waste volumes requiring disposal, recovery of water and a significant reduction in the carbon dioxide emissions of the mining process (Fourie and Jones 2010; Lamont-Black et al., 2008, 2010). The dewatered tailings are suitable for transportation to the disposal site by conveyor (Figure 6).

\section{Discussion}

The idea of electrokinetic geosynthetics emerged from just one of a long string of discussions between an academic and a geosynthetics producer. This was followed by small investigations in a university laboratory prior to funded research programmes. These discussions began in 1993 and the first fully commercial electrokinetic geosynthetics slope stabilisation project was completed in 2012.

It is now over 20 years since the first investigations. Reflecting on the developments during that time, electrokinetic geosynthetics technology has followed the trajectory of technology development characterised by the Gartner hype cycle concept of emerging

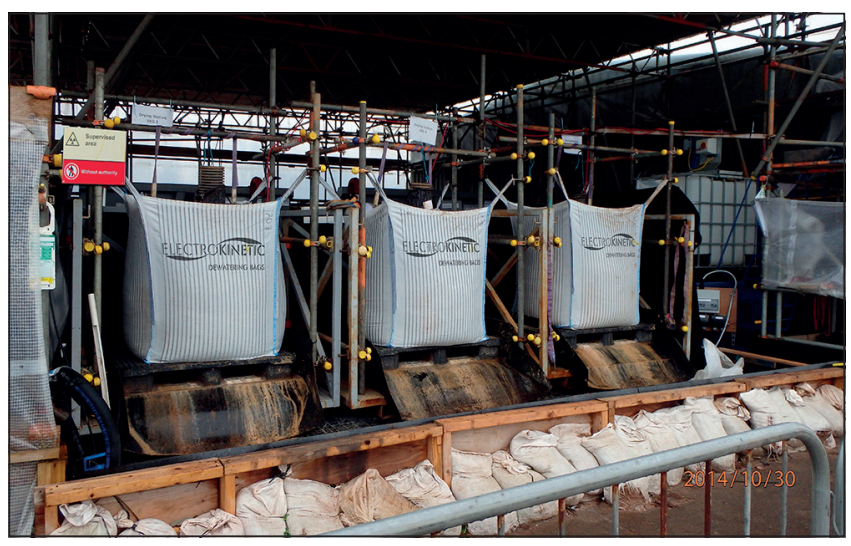

Figure 5. Electrokinetic geosynthetic dewatering of nuclearcontaminated slurry resulted in a $90 \%$ reduction of waste requiring long-term storage

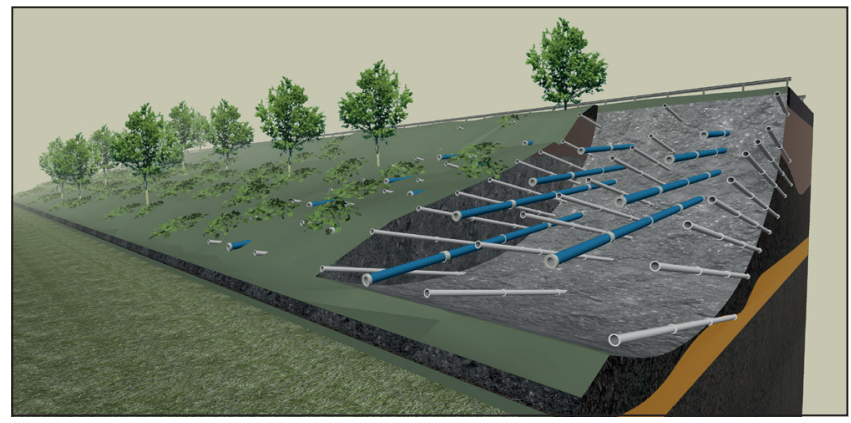

Figure 6. Schematic diagram of an installed electrokinetic geosynthetic slope stabilisation array with anodes and cathodes arranged in columns to provide ground improvement, reinforcement and drainage 


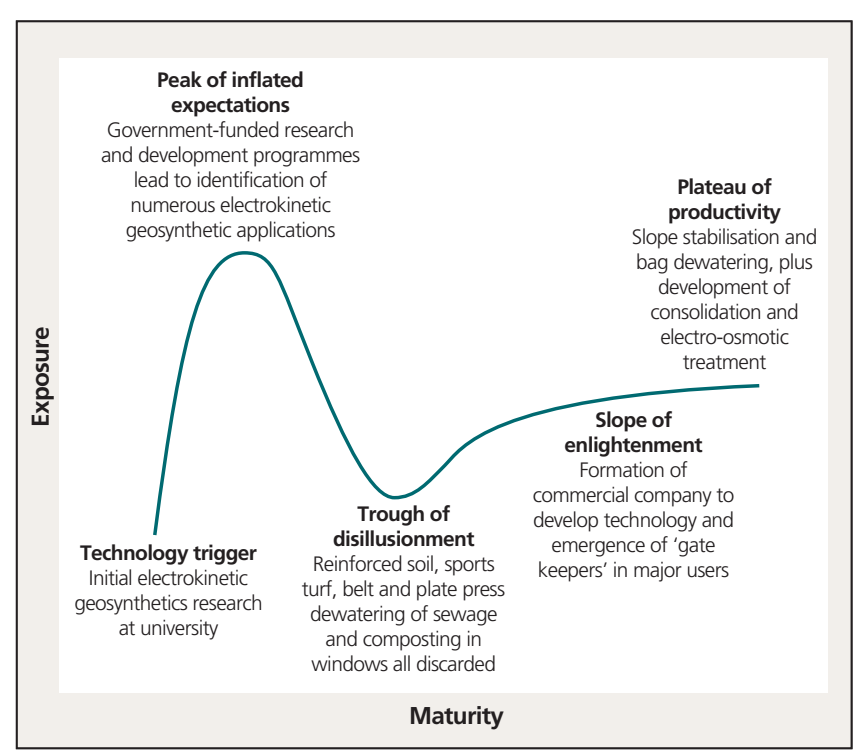

Figure 7. Gartner hype cycle for electrokinetic geosynthetics

technologies (Figure 7) (Fenn and Raskino, 2008). Thus electrokinetic geosynthetics has traced a typical development trajectory from initial concept, early development, hype and descent into disillusionment and emergence into practical application and acceptance. Within electrokinetic geosynthetics technology, four application areas have emerged: two in the UK, one in China and one in South Africa. The development is continuing.

It is frequently observed that it is difficult to get innovation accepted into civil engineering practice, for example in reports such as Construction 2025 (BIS, 2013) and Innovation: Stepping up the Industry (ICE, 2015). Reports variously identify different factors and components that are considered important in developing and implementing innovation within civil engineering. In the case of electrokinetic geosynthetic technology, it is possible to identify six key elements which were critical in taking the technology from initial concept, through research and into practice.

First, resources - in this instance, university laboratories and staff to carry out unfunded research explorations as initial qualifying of the concept and to develop ideas for a research programme. Second, government research funding by way of the EPSRC and co-operation from the geosynthetics industry were fundamental in undertaking the basic research and providing proof of concept.

The third element was the creation of a technology company with private and venture capital to champion the technology. The fourth key factor was the award of government funding to develop the technology to meet the requirements of industry. This could not have been achieved without co-operation and funding from industry. Demonstration of the financial and environmental benefits provided by the technology is critical to the acceptance of innovation.

Although all major sections of the construction industry are tacitly receptive to innovation there is no established mechanism to overcome the inherent conservatism of UK civil engineering practice. The fifth element was the emergence and identification of 'gatekeepers' representing the potential users of the technology. Gatekeepers to innovative technology are rare - they can emerge at any position in an organisation but are usually associated with operations and delivery as opposed to very senior management. The application of electrokinetic geosynthetic technology to practice has benefited from gatekeepers appearing in Highways England, local government and a number of consulting engineers and contractors.

The sixth key factor was the development of design and construction protocols and methods, which are compatible with established standards. Thus the revision of BS 8006 on reinforced soil in 2010, which included the recognition of electrokinetic geosynthetic technology, was timely.

\section{Acknowledgements}

The UK Engineering and Physical Sciences Research Council supported the initial studies and proof of concept of electrokinetic geosynthetics. Durham Waste Management, Kvaerner Cementation Foundations Ltd, Tensar International Ltd, Capitol, Mitsui Geosynthetics, Naue Fasertechnik GmbH, Okasanlivic Co Ltd and New Associates provided materials and funding. The DTI Technology Development Programme included support from Asbrook Simon Hartley, C A Blackwell, Edmund Nuttall, Rio Tinto, Yorkshire Water, Thames Water, Severn Trent Water, GKN, De Beers, Exxaro, Highways England, Network Rail and Entex. Support for the development of the electrokinetic geosynthetic technology has also been provided by Amey, Balfour Beatty, TGP, Afitex, Arcitex, Clear Edge and Technitex Sachsen.

\section{References}

Alder D, Jones CJFP, Lamont-Black J et al. (2015) Design principles and construction insights regarding the use of electrokinetic techniques for slope stabilisation. In Geotechnical Engineering for Infrastructure and Development (Winter MG, Smith DM, Eldred PJL and Toll DG (eds)). ICE Publishing, London, UK, vol. 4, pp. 1531-1536

Bourges-Gastaud S, Stotz G, Dolez P, Blond E and Touze-Foltz N (2015) A laboratory device to characterize electrokinetic geocomposites for fluid fine tailings dewatering. Canadian Geotechnical Journa/ 52(4): 505-514.

BIS (Department for Business, Innovation and Skills) (2013) Construction 2025. BIS, London, UK, URN BIS/13/955.

BSI (1990) BS 1377-3: Methods of test for soils for civil engineering purposes. Chemical and electro-chemical tests. BSI, London, UK.

BSI (2010) BS 8006: Part 1. Code of Practice for strengthened/reinforced soil and other fills. BSI, London, UK.

Eng K and Jones CJFP (1998) Improvements Relating to Geosynthetics. UK Patent GB2301311B, Jun.

EPSRC (Engineering and Physical Sciences Research Council) (1994) Research into New Forms of Geosynthetic Materials. EPSRC, London, UK, GR/K20590/01. EPSRC (1997) Electrokinetic Geosynthetic Materials for use in the Construction Industry. EPSRC, London, UK, GR/L66090/01.

EPSRC (2005) Fluid Abstraction from Liquid Wastes for Waste Minimisation and Resource Recover. EPSRC, London, UK, GRTT04854/01.

Fenn J and Raskino M (2008) Mastering the Hype Cycle. Harvard Business Press, Cambridge, MA, USA.

Fourie $A B$ and Jones CJFP (2010) Improved estimates of power consumption during dewatering of mine tailings using electrokinetic geosynthetics (EKGs). Geotextiles and Geomembranes 28(2): 181-190.

Fourie AB, Pavlakis J and Jones CJFP (2002) Stabilisation of mine tailings deposits using electro-kinetic geotextiles. In Geosynthetics: State of the Art, Recent Developments (Delmas P and Gourc JP (eds)). Balkema, Lisse, the Netherlands, vol. 3, pp. 1031-1034.

Fourie $A B$, Johns $D$ and Jones CJFP (2004) In-situ dewatering of mine tailings using electro-kinetic geosynthetics. In Tailings and Mine Waste '04. CRC Press, Boca Raton, FL, USA, pp. 341-345.

Fourie AB, Johns DG and Jones CJFP (2007) Dewatering of mine waste using electrokinetic geosynthetics. Canadian Geotechnical Journal 44(2): 160-172 
Gendininng S, Jones CJFP and Lamont-Black J (2005a) The use of electrokinetic geosynthetics (EKG) to improve soft soils. In Ground Improvement Case Histories (Indraratna B and Chu J (eds)). Elsevier, Amsterdam, the Netherlands, chapter 35, pp. 997-1044.

Glendinning S, Jones CJFP and Pugh RC (2005b) Reinforced soil using cohesive fill and electrokinetic geosynthetics. International Journal of Geomechanics, ASCE 5(2): 138-146.

Glendinning S, Lamont-Black J and Jones CJFP (2006) Treatment of sewage sludge using electrokinetic geosynthetics. Journal of Hazardous Materials 139(3): 491-499.

Glendinning S, Lamont-Black J, Jones CJFP and Hall J (2008) Treatment of lagooned sewage sludge in situ using electrokinetic geosynthetics. Geosynthetics Internationa/ 15(3): 192-204.

Hall J, Glendinning S, Lamont-Black J and Jones CJFP (2008) Dewatering of waste slurries using electrokinetic geosynthetics (EKGs) filter bags. In EuroGeo4 4th European Geosynthetics Conference (Dixon N (ed.)). International Geosynthetics Society, Jupiter, FL, USA, paper 321 (CD-ROM).

Hamir RB, Jones CJFP and Clarke BG (2001) Electrically conductive geosynthetics for consolidation and reinforced soil. Geotextiles and Geomembranes 19(8): 455-482.

Huntley DT, Lamont-Black J, Jones CJFP and Glendinning S (2006) Economic models for the use of electrokinetic geosynthetics. In Geosynthetics: Proceedings of the 8th International Conference on Geosynthetics (Kuwanao J and Koseki J (eds)). Millpress, Rotterdam, the Netherlands, pp. 543-546.

IGS (International Geosynthetics Society) (1996) Recommended Description of Functions, Geosynthetics Terminology, Mathematical and Graphical Symbols. International Geosynthetics Society, Jupiter, FL, USA.

ICE (Institution of Civil Engineers) (2015) Innovation: Stepping up the Industry. ICE, London, UK.

Jackson C, Lamont-Black J, Alder D and White C (2015) Embankment failure remediation on the M5 junction 7 - a case history of electrokinetic treatment. In Geotechnical Engineering for Infrastructure and Development (Winter MG, Smith DM, Eldred PJL and Toll DG (eds)). ICE Publishing, London, UK, vol. 4, pp. 2007-2012.

Jones CJFP (2000) Developments and innovations in reinforced soil technology. In Landmarks in Earth Reinforcement (Ochiai H, Omine K, Otani J and Yasufuku $\mathrm{N}$ (eds)). Balkema, Lisse, the Netherlands, vol. 1, pp. 1047-1061.

Jones CJFP (2011) Electrokinetic strengthening and repair of slopes. Geo-Strata, ASCE 15(4): 18-26.

Jones CJFP and Pugh RC (2001) A full-scale field trial of electrically enhanced cohesive reinforced soil using electrically conductive geosynthetics. In Landmarks in Earth Reinforcement (Ochiai H, Omine K, Otani J and Yasufuku $\mathrm{N}$ (eds)). Balkema, Lisse, the Netherlands, vol. 1, pp. 219-223.

Jones CJFP, Fakher A, Hamir R and Nettleton IM (1997) Geosynthetic materials with improved reinforcement capabilities. In Earth Reinforcement (Ochiai $\mathrm{H}$, Yasufuku N and Omine K (eds)). Balkema, Rotterdam, the Netherlands, vol. 2, pp. 865-887.

Jones CJFP, Glendinning S and Shim GSC (2002) Soil consolidation using electrically conductive geosynthetics. In Geosynthetics: State of the Art, Recent Developments (Delmas P and Gourc JP (eds)). Balkema, Lisse, the Netherlands, vol. 3, pp. 1039-1042.

Jones CJFP, Lamont-Black J, Glendinning S et al. (2008) Recent research and applications in the use of electrokinetic geosynthetics. In EuroGeo4: 4th European Geosynthetics Conference (Dixon N (ed.)). International Geosynthetics Society, Jupiter, FL, USA, keynote paper (CD-ROM).

Jones CJFP, Lamont-Black J and Glendinning S (2011) Electrokinetic geosynthetics in hydraulic applications. Geotextiles and Geomembranes 29(4): 381-390.

Jones CJFP, Lamont-Black J, Glendinning S, White C and Alder D (2014) The environmental sustainability of electrokinetic geosynthetic strengthened slopes. Proceedings of the Institution of Civil Engineers - Engineering Sustainability 167(3): 95-107.

Lamont-Black J and Jones CJFP (2006) Push-button pitch control. The Groundsman, September: pp. 32-35.

Lamont-Black J, Huntley D, Glendinning S and Jones CJFP (2006a) The use of electrokinetic geosynthetics (EKGs) in enhanced performance of sports turf. In Geosynthetics: Proceedings of the 8th International Conference on Geosynthetics (Kuwanao J and Koseki J (eds)). Millpress, Rotterdam, the Netherlands, pp. 453-456.

Lamont-Black J, Huntley D, Glendinning S and Jones CJFP (2006b) The use of electrokinetic geosynthetics (EKGs) in belt press dewatering. In Geosynthetics:
Proceedings of the 8th International Conference on Geosynthetics (Kuwanao and Koseki J (eds)). Millpress, Rotterdam, the Netherlands, pp. 535-538.

Lamont-Black J, Huntley DT, Jones CJFP, Glendinning S and Hall J (2007a) Electrokinetic soil nailing for the strengthening or repair of failures of clay slopes and cuttings. In New Horizons in Earth Reinforcement (Otani J, Miyata Y and Mukunoki T (eds)). CRC Press, Boca Raton, FL, USA, pp. 681-684.

Lamont-Black J, Jones CJFP, Glendinning S, Huntley D and Fourie A (2007b) Laboratory evaluation of the potential for electrokinetic belt filter press dewatering of Kimberlite slimes. In Paste 2007: Proceedings of the Tenth International Seminar on Paste and Thickened Tailings (Fourie A and Jewell $\mathrm{R}(\mathrm{eds}))$. Australian Centre for Geomechanics, Crawley, WA, Australia, pp. 147-152.

Lamont-Black J, Huntley DT, Jones CJFP, Glendinning S and Hall J (2008) Electrokinetic strenghtening of tailings. In Paste 2008: Proceedings of the Eleventh International Seminar on Paste and Thickened Tailings (Fourie A, Jewell R, Slatter P and Paterson A (eds)). Australian Centre for Geomechanics, Crawley, WA, Australia, pp. 211-224.

Lamont-Black J, Jones CJFP, Fourie AB and Kruger L (2010) Electrokinetic belt press dewatering of kimberlite tailings - case study of a full scale field trial. In Paste 2010: Proceedings of the Thirteenth International Seminar on Paste and Thickened Tailings (Fourie A and Jewell R (eds)). Australian Centre for Geomechanics, Crawley, WA, Australia, vol. 1, pp. 329-342.

Lamont-Black J, Hall JA, Glendinning S, Jones CJFP and White C (2012) Stabilisation of a railway embankment using electrokinetic geosynthetics. Engineering Geology Special Publications 26: 125-139.

Lamont-Black J, Jones CJFP and White C (2015) Electrokinetic geosynthetic dewatering of nuclear contaminated waste. Geotextiles and Geombranes 43(4): 359-362.

Lamont-Black J, Jones CJFP and Alder D (2016). Electrokinetic strengthening of slopes - case history. Geotextiles and Geombranes 44(3): 319-331.

McLoughlin PW (2005) Belt filter press - fact or fiction? Proceedings of the 10th European Biosolids and Biowaste Conference, Wakefield, UK, paper 45.

Netlon Ltd (1998) Electrically-Conducting Element. UK Patent Application GB 2327686A.

Nettleton IM, Jones CJFP, Clarke BG and Hamir R (1998) Electrokinetic geosynthetics and their applications. In Proceedings of the 6 th International Conference on Geosynthetics (Rowe RK (ed.)). Industrial Fabrics Association International, Roseville, MN, USA, vol. 2, pp. 871-876.

Pavlakis J, Fourie AF and Jones CJFP (2001) Stabilisation of mine tailings deposits using electrokinetic geotextiles. Proceedings of the 4th Conference on Environmental Engineering, Mulderschift, South Africa.

Pavlakis J, Fourie AB and Jones CJFP (2002) Electrophoretic dewatering of mine tailings using geosynthetics. In Geosynthetics: State of the Art, Recent Developments (Delmas P and Gourc JP (eds)). Balkema, Lisse, the Netherlands, vol. 4, pp. 1581-1584

Pugh RC, Clarke BG and Jones CJFP (2000) An electro-osmotic consolidation trial using electrokinetic geosynthetics. In Proceedings of the 4th International Conference on Ground Improvement Geosystems (Rathmeyer H (ed.)). Finnish Geotechnical Society, Helsinki, Finland, pp. 533-540.

Smoluchowski M (1914) In Handbuch der Elektrizitat und Magnetisums (Graetz บA (ed.)). Barth, Leipzig, Germany, vol. 2.

TSB (Technology Strategy Board) (2005) Treatment of Wastes, Slurries and Soils with Electrokinetic Geosynthetics (EKGs). Department for Trade and Industry, London, UK, Technology Programme Grant 15971.

Walker J and Glendinning S (2002) In-situ dewatering of lagooned sewage sludge using electrokinetic geosynthetics (EKGs). Proceedings of the 7th European Biosolids and Organic Residuals Conference, Wakefield, UK.

White C, Glendinning S, Lamont-Black J, Jones CJFP and Taylor T (2008) The application of electrokinetic geosynthetics in the advanced conditioning and composting process of sewage sludge. In EuroGeo4: 4th European Geosynthetics Conference (Dixon N (ed.)). International Geosynthetics Society, Jupiter, FL, USA (CD-ROM).

Zhuang YF (2015) Challenges of electro-osmotic consolidation in large scale application. In Geosynthetics 2015. Industrial Fabrics Association International, Roseville, MN, USA, pp. 447-449.

Zhuang YF and Wang Z (2005) Electric charge accumulation theory for electroosmosis consolidation. Rock and Soil Mechanics 26(4): 629-632.

Zhuang YF, Huang Y, Lui F, Zou W and Li Z (2014) Case study of hydraulic reclaimed sludge consolidation using electrokinetic geosynthetics. Proceedings of the 10th International Conference on Geosynthetics, Berlin, Germany. 